\title{
Transplantation with allogenic bone marrow from a donor with systemic lupus erythematosus (SLE): successful outcome in the recipient and induction of an SLE flare in the donor
}

\author{
G Sturfelt, S Lenhoff, B Sallerfors, O Nived, L Truedsson, A G Sjöholm
}

University Hospital of Lund, Lund, Sweden: Department of Rheumatology G Sturfelt

O Nived

Department of

Medicine

$S$ Lenhoff

B Sallerfors

Department of Medical Microbiology

L Truedsson A G Sjöholm

Correspondence to: Gunnar Sturfelt MD, PhD, Department of

Rheumatology, Lund

University Hospital, S-22185

Lund, Sweden.

\begin{abstract}
Objective-To investigate the transfer of autoimmunity by allogenic bone marrow transplantation.

Methods-Bone marrow transplantation was performed in a 43 years old man with acute myeloid leukaemia (AML) in remission. The donor was his HLA identical brother who had a mild systemic lupus erythematosus (SLE). Autoantibodies, including antinuclear, anti-C1q, and anticardiolipin antibodies, were measured before and after transplantation.

Results-Transient mild graft versus host disease (GvHD) developed in the recipient in the weeks following transplantation. The donor had persistently high concentrations of anti-C1q antibodies to the collagenous region of the complement component C1q. Three months after transplantation the recipient developed antiC1q antibodies that persisted for two months. No other autoantibodies and no SLE-like manifestations appeared. Chronic GVHD started five months posttransplant and responded to intensified immunosuppressive treatment. Three years post-transplant the patient was in unmaintained remission. Within a few weeks after bone marrow donation the donor's disease was exacerbated with development of severe pulmonary alveolitis which required treatment with cyclophosphamide.

Conclusions-When bone marrow transplantation was performed in a patient with AML with bone marrow from an HLA identical brother who had SLE, no evidence of transfer of disease was obtained. However, the recipient temporarily produced anti-C1q antibodies which was a characteristic feature of the donor's SLE and was probably produced by the transplant. The flare of the donor's SLE might be related to the bone marrow tap.
\end{abstract}

(Ann Rheum Dis 1996;55:638-641)
It has recently been shown that systemic lupus erythematosus (SLE) related autoantibody production is determined by bone marrow derived cells ${ }^{12}$ which implies that allogenic bone marrow transplantation might result in an autoimmune reaction in the recipient. Transfer of autoimmune thrombocytopenic purpura, myasthenia gravis, autoimmune thyroiditis, and insulin dependent diabetes mellitus has been proposed in case reports. ${ }^{3} \mathrm{We}$ here describe clinical and laboratory features after allogenic bone marrow transplantation where the recipient had acute myeloid leukaemia (AML) in second remission and the donor had stable inactive SLE.

\section{Case reports}

The patients belonged to a family in which several members had SLE. A pedigree including the results of immunogenetic analysis is shown in the figure.

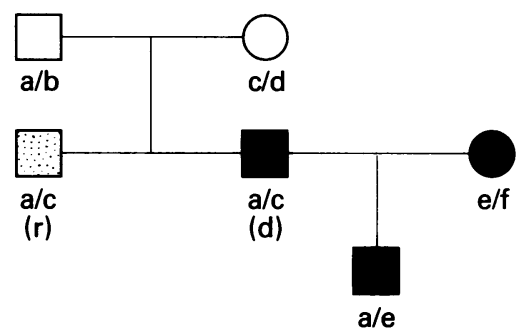

\begin{tabular}{l|llllll}
\hline Haplotype & A & C & B & Compl & DR & DQ \\
\hline a & 1 & w7 & 8 & SC01 & 17 & 2 \\
b & 2 & w3 & 15 & SC30 & 1 & 5 \\
c & 26 & w7 & 8 & SC01 & 17 & 2 \\
d & 1 & w6 & 13 & SC31 & 7 & 2 \\
e & 3 & w6 & 12 & SC31 & 4 & 7 \\
f & 3 & w7 & 7 & SC31 & 15 & 6 \\
\hline
\end{tabular}

Pedigree of the family to which the recipient ( $r$ ) (hatched symbol) and the donor (d) (filled symbol) belonged. Notably the donor's wife and his son also had SLE. Individuals with established SLE diagnosis are marked by filled symbols. 
BEFORE TRANSPLANTATION

Bone marrow transplant recipient

The recipient was a 43 year old man who was admitted to hospital with fever and muscular pain in February 1991. He was diagnosed as having AML morphologically (M5b FAB classification), with results of immune phenotyping consistent with this diagnosis. Cytogenetic examination was normal. Complete remission was achieved after one course of chemotherapy, after which the patient received another three courses for consolidation. In March 1992 the patient relapsed, eight months after the last consolidation course. Morphological and cytogenetic features were the same as at diagnosis. Reinduction chemotherapy was given, and the patient promptly entered a new remission. After two consolidation courses, the patient was admitted for allogenic bone marrow transplantation with his brother as an HLA identical donor.

\section{Bone marrow transplant donor}

The donor was 58 years old at the time of bone marrow transplantation. Nine years earlier he had developed polyarthritis, fever, pleurisy, and mild glomerulonephritis. Severe sun sensitivity with a vesicular-bullous reaction had been developed during the previous summer. Serological analysis revealed positive antinuclear antibodies (ANA) at a titre of 1/100 (rat liver substrate). Antibodies to dsDNA, Sm, RNP, SSB, and rheumatoid factors were not found. The serum contained high concentrations of IgG antibodies to the collagenous region of C1q. ${ }^{4}$ Complement analysis showed low C4 concentrations (30-40\% of normal), but essentially normal C1q levels. The low C4 values were most probably due to homozygous C4A deficiency (figure). A kidney biopsy showed epimembranous glomerulonephritis. Chest $x$ ray at presentation showed minor interstitial basal infiltrations that had disappeared four weeks later. Pulmonary function was normal. A diagnosis of SLE was made, based on presence of a multisystemic disease and ANA positivity. The patient fulfilled five of the ACR classification criteria for SLE. ${ }^{5}$ He was treated with glucocorticoids and antimalarial drugs and responded well to the treatment.

The patient's disease remained stable during the following years. By the time his brother developed AML he was feeling well, was without medication, and thorough investigation revealed no evidence of active SLE. He was willing to donate bone marrow.

\section{AFTER TRANSPLANTATION}

Bone marrow transplant recipient

The transplant was performed in July 1992. Myeloablative treatment consisted of busulphan $16 \mathrm{mg} / \mathrm{kg}$ and cyclophosphamide 120 $\mathrm{mg} / \mathrm{kg}$ body weight. Bone marrow (1.5 litre) was aspirated from the donor and given unmanipulated. The nucleated cell dose was $1.83 \times$ $10^{8} / \mathrm{kg}$, and the CFU-GM content was $3.72 \times$ $10^{4} / \mathrm{kg}$. Neutrophil engraftment $(>0.5 \times$ $10^{9}$ /litre) was reached at day 25 , and platelet
Table 1 Antibodies against $C 1 q$ and clinical events in the donor-SLE patient during the reported time period.

\begin{tabular}{|c|c|c|}
\hline & $\begin{array}{l}\text { Anti-C1 } q \text { antibodies } \\
\text { (U/litre) }\end{array}$ & Clinical events \\
\hline 880620 & 1000 & Arthritis \\
\hline 900110 & 800 & $\begin{array}{l}\text { No clinical } \\
\text { symptoms }\end{array}$ \\
\hline 920623 & 420 & $\begin{array}{l}\text { No clinical } \\
\text { symptoms }\end{array}$ \\
\hline 921211 & 820 & $\begin{array}{l}\text { Slight cough, } \\
\text { tiredness }\end{array}$ \\
\hline 930310 & 1060 & $\begin{array}{l}\text { Dyspnoea, cough, } \\
\text { diagnosis of } \\
\text { alveolitis } \\
\text { established }\end{array}$ \\
\hline 930423 & 69 & $\begin{array}{l}\text { Stable lung } \\
\text { function with } \\
\text { pulmonary } \\
\text { fibrosis }\end{array}$ \\
\hline
\end{tabular}

engraftment ( $>20 \times 10^{9} /$ litre) at day 30 after the transplant. No severe early complications occurred. Graft versus host disease (GvHD) prophylaxis was given with cyclosporin $\mathrm{A}$ and a short course of methotrexate. Mild acute GvHD (skin grade 1) occurred between days 25 and 42 after the transplant. Tests for antinuclear antibodies and rheumatoid factor were consistently negative. Low concentrations of anti-Clq antibodies appeared in the recipient's serum after two months and remained present for at least another month (table 1). The patient developed haemorrhagic cystitis, and cytomegalovirus and polyoma virus were isolated from the urine. Treatment was given with high dose intravenous immunoglobulins and the symptoms disappeared after three weeks. In December 1992, five months after the transplant, the patient showed signs of chronic GvHD, with symptoms mainly relating to the oral cavity, the eyes, and the liver. Platelet counts were moderately decreased. Repeated upper respiratory tract infections occurred during the spring of 1993, in conjunction with mild obstructive lung function impairment. Increased dosage of cyclosporin A improved the condition. The patient's chronic GvHD remained mild to moderate. No additive immunosuppressive treatment was required. $\mathrm{He}$ was in unmaintained second remission 30 months after the transplant.

\section{Bone marrow transplant donor}

Six months after bone marrow donation the donor began to feel tired and developed cough problems that were exacerbated at night. $X$ ray of the lungs showed interstitial infiltration, and spirometry revealed restrictive lung dysfunction. Total lung capacity (TLC) was 2.6 litres (normal 6.9), forced expiratory volume in one second $\left(\mathrm{FEV}_{1}\right) 1.7$ litres (normal 3.4 litres), and $\mathrm{CO}$ diffusion capacity (DLCO) $3.8 \mathrm{mmol} /$ min $\mathrm{kPa}$. A lung biopsy was performed, showing active alveolitis and slight fibrosis. His anti$\mathrm{Clq}$ antibodies increased in concentration (table 2) and C1q and C4 levels were slightly low. Apart from moderately raised IgG, C reactive protein, and erythrocyte sedimentation rate, the other laboratory findings were essentially normal. 
Table 2 Antibodies against C1q and clinical events in the bone marrow recipient during the reported time period.

\begin{tabular}{|c|c|c|}
\hline & $\begin{array}{l}\text { Anti-C1q antibodies } \\
\text { (Ullitre) }\end{array}$ & Clinical events \\
\hline $\begin{array}{l}920715 \\
920730\end{array}$ & $\begin{array}{l}<16 \\
<16\end{array}$ & BMT \\
\hline 920824 & $<16$ & $\begin{array}{l}\text { Mild acute } \\
\text { GvHD }\end{array}$ \\
\hline 920924 & 24 & $\begin{array}{l}\text { Haemorrhagic } \\
\text { cystitis }\end{array}$ \\
\hline $\begin{array}{l}921021 \\
921125\end{array}$ & $\begin{array}{l}18 \\
<16\end{array}$ & $\begin{array}{l}\text { iv IgG treatment } \\
\text { Mild chronic } \\
\text { GvHD }\end{array}$ \\
\hline
\end{tabular}

BMT, bone marrow transplant; GvHD, graft $v$ host disease.

Treatment with glucocorticoids and cyclophosphamide was begun and this stabilised lung function. In July 1994, TLC was 2.9 litres, $\mathrm{FEV}_{1} 1.9$ litres, and DLCO 3.8 $\mathrm{mmol} / \mathrm{min} \mathrm{kPa}$. The interstitial lung changes persisted as estimated by $x$ ray, but high resolution computerised tomography revealed gradually decreasing inflammatory activity. There was no evidence of kidney involvement during this period. The patient has retired from his work. His daily activities were restricted by dyspnoea during mild exercise at the time of writing (July 1995).

\section{Discussion}

SLE is a systemic inflammatory disease characterised by multiple organ manifestations and immunological disturbances. Increased B cell activity with production of a broad range of autoantibodies are common findings. In the present study a bone marrow transplant was performed with transfer of bone marrow from a male SLE patient to his brother with AML. The brothers had identical extended MHC haplotypes [HLA-A1,Cw7,B8,SC01,DR17, DQ1] and [HLA- A26,Cw7,B8,SC01,DR17, DQ2] (see the figure), previously shown to be associated with disease susceptibility in multicase SLE families. ${ }^{6}$

There is little experience of bone marrow transplantation in human autoimmune disease. Liu Yin and Jowitt ${ }^{7}$ reported persistent remission of psoriasis and ulcerative colitis in two patients who received allogenic marrow grafts from histocompatible relatives because of leukaemia. These results are, however, difficult to interpret because of the complex post-transplant immunological situation. Another problem relevant to our cases is the possibility of adoptive autoimmunity in the recipient. The donor had unusually high concentrations of anti-Clq antibodies and two months after bone marrow transplantation small amounts of anti-C1q antibodies were transiently present in the recipient's serum. No other autoantibodies were detected. The antibodies had disappeared two months later, during which time he was on low dose cyclosporin A and also had been treated with intravenous IgG because of haemorrhagic cystitis. We found no evidence of SLE in the recipient and no autoantibodies were detected when he later developed a moderate chronic GvHD. Minchinton et $a^{3}$ reported a case where the recipient developed IgM antiplatelet antibodies and thrombocytopenia. The throm- bocytopenia was successfully treated with high dose intravenous IgG without relapse. In another report, an aplastic anaemia patient developed myasthenia gravis with acetylcholine receptor antibodies after bone marrow transplantation from a sibling. ${ }^{8}$ Interestingly, Fremeaux-Bacchi et $a l^{9}$ recently reported the selective disappearance of $\mathrm{C} 3$ nephritic factor activity in the plasma of a patient with membranoproliferative glomerulonephritis following renal transplantation combined with bilateral nephrectomy, indicating that the autoantibody response was antigen driven. By analogy, the disappearance of anti-C1q antibodies in the recipient is consistent with a requirement of an antigen driven process.

In our patient we could not document evidence of transfer of disease. However, the recipient temporarily produced anti-C1q antibodies, but no other autoantibodies, which would have suggested an autoimmune reaction. Experimental findings suggest that autoantibody production is determined by bone marrow derived cells. ${ }^{2}$ Most probably, the anti-C1q antibodies in the recipient were produced by the transplant.

Before the bone marrow transplant, the disease activity of the donor's SLE had remained low for several years. Six months after the transplant the patient unexpectedly developed a severe flare with progressive alveolitis and increasing concentration of antiClq antibodies. To account for the unusual combination of high anti-C1q antibodies and alveolitis the possibility should be considered that some anti-Clq antibodies cross react with the Clq-like molecules such as lung surfactant proteins $\mathrm{A}$ and $\mathrm{D} .^{10} \mathrm{Clq}$-like antibodies are usually associated with kidney involvement in SLE but besides a mild epimembranous glomerulonephritis at the start of the disease no evidence of renal disease was found in the patient. $^{11}$ A rebound phenomenon with increased antibody production has been described in patients with autoimmune diseases treated with plasma exchange without concomitant immunosuppressive treatment. ${ }^{12}$ It is conceivable that the bone marrow tap with reactive increased production and activity of immunological cells might have contributed to the severe flare in our SLE patient. Careful observation is warranted in patients with immunological disease when treatment procedures interfere with immunological function.

This work was supported by Swedish Medical Research CounThil (07921 and 09528), the Medical Faculty of the University of
Lund, The Swedish National Association against Rheumatism, Lund, The Swedish National Association against Rheumatism, dation, Greta and Johan Kock's Foundation, Georg Danielssons Foundation, Professor Nanna Svartz' Foundation and Lunds sjukvårdsdistrikt.

1 van Bekkum DW. BMT in experimental autoimmune diseases. Bone Marrow Transplant 1993;11:183-7.

2 Levite M, Zinger H, Moses E, Reisner Y. Systemic lupus erythematosus-related autoantibody production in mice is Bells. Bome Marrow Transplant 1993;12:179-83.

3 Minchinton RM, Waters A, Kendra J, Barret AJ. Autoimmune thrombocytopenia acquired from an allogenic bone mune thrombocytopenia acquired from

4 Mårtensson U, Sjöholm AG, Sturfelt G, Truedsson L, Laurell $\mathrm{AB}$. Western blot analysis of human IgG reactive with 
the collagenous portion of $\mathrm{Clq}$ : evidence of distinct binding specificities. Scand f Immunol 1992;35:735-44.

5 Tan EM, Cohen AS, Fries JF, Masi AT, McShane DJ, Rothfield NF, et al. The 1982 revised criteria for the classification of systemic lupus erythematosus. Arthritis Rheum 1982;25:1271-7.

6 Truedsson L, Sturfelt G, Johansen P, Nived O, Thureson B. Sharing of MHC haplotypes among systemic lupus erythematosus patients from unrelated caucasian multiplex families: disease association with the extended haplotype [HIAB8,SC01,DR17]. F Rheromatol 1995;22:1852-61.

7 Liu Yin JA, Jowitt SN. Resolution of immune-mediated diseases following allogenic bone marrow transplantation for leukaemia. Bone Marrow Transplant 1992;9:31-3.

8 Smith CIE, Aocti JA, Biberfeld RL, Bolme P, Christensson B, Gahrton G, et al. Myasthenia gravis after bone marrow transplantation: evidence for a donor origin. $N$ Engl $\mathcal{F} M e d$ 1983;309:1565-8.

9 Fremeaux-Bacchi V, Weiss L, Brun P, Kazatchkine MD. Selective disappearance of C3NeF IgG autoantibody in plasma of a patient with membranoproliferative glomerulonephritis following renal transplantation. Nephrol Dial Transplant 1994;9:811-4.

10 Holmskov U, Malhotra R, Sim RB, Jensenius JC. Collectins: collagenous C-type lectins of the innate immune defense system. Immunol Today 1994;15:67-73.

11 Sjöholm AG, Mårtensson U, Klareskog L, Sturfelt G. Seria analysis of autoantibody response to the collagen-like region of in patients with systemic lupus erythematosus. $\mathcal{f}$ Rheumain patients with

12 Schlansky R, DeHoratius RJ, Pincus T, Tung KSK Plasmapheresis in systemic lupus erythematosus - a cautionary note. Arthritis Rheum 1981;24:49-53. 